\title{
Characteristics of Small and Medium Enterprise Innovativeness: Cases of Uzbekistan and China
}

\author{
Ahunjonov Umidjon, Hu Shuhua, Bandula Jayathilake, Mu Renyan \\ School of Management, Wuhan University of Technology \\ E-mail (corresponding author): umidahun@gmail.com
}

\begin{abstract}
In this study, we aim at investigating factors significantly affecting innovation behavior of SMEs in developing country context. To realize the research objective, a thorough literature view on SME innovativeness has been realized and initial model for the study has been constructed. Data collected by selfadministered questionnaire from SME CEOs and high level managers of Uzbekistan and China sample SMEs has been analyzed by Multivariate Logistic Model to make inference about significant determinants of SME innovativeness. The findings of the study suggest that CEOs with higher education, their innovation goaloriented determination, and competition pressure from home market and abroad due to high export orientation of the SME and government incentives for innovations are being main forces making SMEs realize innovations. Internally, innovative SMEs are being led by CEOs with higher education degree and who well fits the great importance of innovations in their company strategy.
\end{abstract}

Key words: Small and Medium Enterprise, Affecting Factors, Innovativeness, China, Uzbekistan

\section{Introduction}

There are several research studies conducted to identify factors exert influence on SME innovativeness (Keizer, 2002; Hoffman, 1998; Radas, 2009). However, firstly, almost all of such studies measured factors of SME innovativeness in the case of developed economies, mostly concentrating on single country sample or qualitative interviews with managers (Laforet, 2008). Taking a study on antecedents of SME innovativeness in Croatian SME case, (Radas, 2009) suggests future research needs to be conducted in the example of several countries simultaneously to get generalizable results. Besides, many studies either investigated the impact of limited set of determinants on innovativeness or this issue was examined in the sample of companies other than SMEs. To our knowledge, other than Keizer (2002), who conducted analysis on determinants of innovation efforts in the example of the Netherlands manufacturing firms, which is also a developed country, no one else have focused on possible interactions between different factor variables of SME innovativeness.

Considering the shortcomings of previous researches and also taking suggestions of previous literature on this topic, our study intends to take a holistic look on different factors of SME innovativeness in developing countries and tries to determine significant factors on SME innovativeness, taking into account the existing 
interaction between critical factors. Following Keizer (2002) we have divided factors into internal and external.

\section{Internal factors bearing to firm innovativeness}

\subsubsection{Firm characteristics and firm size}

Internal factors refer to characteristics and policies of SME which are believed to have some impact on its innovativeness (Keizer, 2002). Relationship between firm size and innovations has been the topic of several recent researches and they mostly yield somewhat contradictory results. While firm size is pointed to be the predictor of firm innovativeness by many recent research studies, some other findings tell different stories on its effect on innovative activeness of the firm. Some researches claim that smaller firms are more innovative (Gabsi, 2008; Stock, 2002; Hansen, 1992) while others point that small size broadly reduces the probability of innovation (Huergo, 2004) where larger size is assumed to have a key enabling condition for making innovations happen (Laforet, 2006). Most of the time, as stated by Hansen (1992), contribution of small firms to innovation is considerable understated by the R\&D data and other inputs; in reality they do innovate better and more in number (research was undertaken in the example of US firms). Research work done in the case of French biotechnology industry (Pla-Barber, 2007) yields no relationship between innovations and firm size and strongly suggests the industrial setting (such as difference between science-based and other industries) to be taken into account in measuring the relationship between these two variables. Stock (2002) finds small firms to be comparatively more innovative than bigger ones in his longitudinal research analysis in computer modem industry. There is a third group which asserts small and large firms to be more innovative than intermediate size firms (Bertschek, 1996). As a resolving point Santarelli (1990) says that smaller firms are better in incremental while the bigger ones are in radical innovations.

So, we hypothesize:

H1a: Size of SME is a determinant of its innovativeness behavior

\subsubsection{Firm age}

Firm age effect to propensity of innovations also yields different empirical results. Researchers such as (Hansen, 1992) and (Huergo, 2004) (sample of US and Spanish firms respectively) ascertain that entrant firms tend to present higher probability of innovation while the older firms tend to show lower innovative probabilities. (Shefer, 2005) speaks about start-ups in high-tech industry which are highly innovative regardless of their newly-born age and small size (in the sample of Israeli manufacturing firms). In (Koberg ,2003) older age of firms is associated with incremental innovations (in the sample of aerospace, electronics and telecommunication companies which belong to large company category).

So, we hypothesize:

$\mathrm{H} 1 \mathrm{~b}$ : Age of SME is a determinant of its innovativeness behavior

\subsubsection{Proportion of qualified personnel}

Highly qualified employees are considered as a knowledge base of the company, a source of ideas and inspiration for innovations (Radas, 2009). Similarly, having high proportion of qualified scientists and university-trained engineers is the most important determinants of innovative activity (Hoffman, 1998; Romijn, 2002). Literature (Radas, 2009; Marco, 1995) shows that high incidence of qualified personnel, along with skills and knowledge embodied with them, positively affects firm's innovative capability. Tessa (2004) by identifying small food manufacturing firms from six rural areas of the EU as non-innovators and innovators (traditionalists, followers and leaders) empirically substantiates that firms with higher number and higher proportion of qualified technical staff are more innovative. (Frederic, 2002), in his research in case of French SMEs, runs a conclusive assumption that qualified employees are essential in SMEs both for their better 
ability to absorb information flow from external sources (implying higher dependence of SMEs on external sources) to innovate and also for their importance to structure firms' own innovation capacity. Lacking absorptive capacity in SMEs and firms in traditional industries has been raised as a problem (Andre, 2011). Universities are deemed to be hotbeds of innovation mainly because they produce a supply of highly skilled graduates who are highly important in implementing innovative products and processes in the private sector (PwC, 2010).

So, we hypothesize:

H1c: SMEs with higher proportion of educated workers shows higher innovativeness

\subsection{CEO characteristics}

\subsubsection{Educational background of CEO}

Educational background of managing director is widely believed to be a key source of firm innovative efforts (Hoffman, 1998). Because attained education level is attributed to cognitive ability, capacity for information processing, tolerance for ambiguity and propensity or receptivity to innovation; CEOs with higher educational level is found to invest more in R\&D and do it more (Datta, 1994; Yan Yong-hai, 2010). Another study (Barker, 2002) finds significant R\&D spending increase with firms where CEOs have advanced sciencerelated degrees. Level of education influences the receptiveness of executives to external sources and their approach to innovation problems (Frederic, 2002): executives with lower level of education rely more on their own knowledge at the time when they confront a complex problem even if the problem remains unsolved or wrongly solved whereas those with higher level of education recognize the problem to be beyond (if it is) their competencies to resolve and know whom to contact to get right answer and reach appropriate solution in the end. Higher educational levels of owners/managers (mainly technical and vocational qualifications) correspond to higher level of innovations in SMEs (Mohamed, 2005) and their provision of wider range of business related development courses and activities for the staff which is also essential for the development of higher absorptive capacity in the firm (Colin, 2006). CEO education level positively associated with firm's innovation efforts (Lin, 2011). In developed countries there are policy instruments aimed at building national capacity to lead in new science-based technologies and industries through promoting science entrepreneurship where science geeks are pushed into a market place to run business activity (Lehrer, 2004).

Positive effects of returnee entrepreneurs on innovation are highly discussed in China and India case (Xiaohui et al., 2010; AnnaLee, 2005). South Korean and Taiwanese innovation-driven economic success is linked with these countries' ability to attract their students to return from developed countries, namely from the USA (Joan, 2002). Technology is said to be diffused across regions and countries by different transmission mechanisms one of which is foreign education of students and workers (Xiaolan, 2011). Jeff et al. (2011) after his studies of the habits of innovative entrepreneurs conclude that innovative entrepreneurs stand out with their "networking" features. Their "networking" skill is said to be greatly enhanced by their visit to other countries and meet different people.

So, we hypothesize:

H1d: CEOs with higher educational degree have higher impact on SME innovativeness

H1e: CEOs with foreign degree have higher impact on SME innovativeness in comparison to CEOs with home country degree

\subsubsection{CEO Perception of innovation}

CEO is a core figure in the company who has an important impact on the development of organizational vision and sets proper strategies to attain it. Their attention is a critical determinant of innovation and plays a leading role in promoting innovation within firms (Manjit, 2007). Marianna (2010) posits a concept of creative and operational leadership implying CEO characteristics and attitude towards innovation. She empirically 
substantiates that both types of leaders positively affects innovation quantity while creative leadership is most important for enhancing innovation novelty and quality. In explaining positive effect of significantly changed corporate strategies on innovations in SMEs, (Radas, 2009) sees the role of top management (including CEO) to play a very influential position. In the same way, research from (Colin, 2006) presents that owner's strategic objectives are crucial to the development and use of innovation which eventually drive the firm to compete successfully. (Laforet, 2006) finds the CEO to be more involved in innovative group of small manufacturing firms in developing new products, processes and ways of working compared to their less innovative counterparts and also emphasizes important role of strategic orientation in realizing innovations.

There are also some studies which have hypothesized and checked the relationship between traits of entrepreneurs towards innovation performance of the firm. One of such studies from Alberto (2008) demonstrates the importance of personality related features of entrepreneur, degree of openness to newness and predisposition to be among the firsts to adopt innovations in a specific domain, in his/her intention to adopt innovations. Entrepreneur's traits namely achievement motivation, risk taking propensity and preference for innovations have been hypothesized to have some impact on SME performance by (Ignas, 2012) as well. (Krishnaswamy, 2014) also emphasizes that entrepreneur plays an instrumental role in realizing innovations and finally delivering these innovations into the market.

So, we hypothesize:

H1f: Innovation oriented leaders have positive impact on SME innovativeness

\subsection{Innovation Capabilities}

\subsubsection{Employee engagement in innovation process}

There are several sources which companies use to get ideas for realizing innovations. Using the creativity of employees is one of these many sources. "Tacit knowledge" embodied in individual - company employee (defined as a "practical man") plays a very central role both in product and process development (Povl et.al., 1997) particularly in low-tech firms. One relevant fact is that not all companies use the creativity of its employees: the research interest posed here is if the ones which are involving employees to innovation process are more innovative than the ones which are not. Employee suggestion scheme with regard to innovation distinguishes the difference between more and less innovative firms (Laforet; 2006). Jon (1996) states the empowerment (involvement of employees in the innovation process) as corporate entrepreneurship in the innovation process and discusses the need of appropriate strategic approach to innovation by emphasizing the human resource as an innovative capability. Encouraging employees to try novel ways of doing things, searching for new solutions and giving them sufficient time to pursue their creative ideas all improve the climate for innovation (Roman, 2012). Pro innovative culture or, in some explanations, leadership culture is required to involve employees into the process of business policy formulation and innovative idea creation which in the end contribute to the increase of firm innovation capability (Minna, 2014; Lubica, 2014).

So, we hypothesize:

H1g: Employee engagement in innovation (ideation) process leads to higher innovativeness of SMEs

\subsubsection{IT capabilities}

Many researchers have found IT capabilities of small and medium sized enterprises to be linked to their increased firm performance, internalization and consequentially their innovativeness. Roman (2012) finds the usage of IT in SME internal communication to have positive effect on innovation activity. (Carbonara , 2005) also states that by facilitating exchanges of opinions, information sharing and work coordination, IT can contribute to innovation. (Zhang Man, 2008), taking an empirical study on Chines export-focused SMEs, recognizes IT capability of SMEs to be the potential for enhancing effectiveness and performance in such firms. Cheng (2005) states positive effect of innovation and IT capital interaction to firms' performance. There are also many researchers who state the contribution of IT such as email, discussion forums, online 
surveys and other internet-based toolkits in harnessing consumer creativity for new product development process (Desouza et al., 2008, Von Hippel, 2005). Software application is associated with a significant increase in the extent and quality of product design and decrease time spent on it (Banker, 2006) and more innovative group of small manufacturing firms are found to use computer-aided design (CAD) and computeraided manufacturing (CAM) processes twice/three times more respectively than their less innovative counterparts (Laforet, 2006). Internet, an accessible knowledge sources, has been defined as one of the sources of organizational search, a search which is defined as firm's attempt to recognize the value of new external knowledge to apply it to commercial ends (Ignas, 2012). In a wider context, such as in considering innovation potential of the region or specific country, ICT (information-communication technologies which are mainly telephone, computers and Internet) is taken as the main indicator implying its role in reduced uncertainty and transaction costs, growth of information and knowledge flow, productivity and cross-border competition and finally rapid spread of innovations (Kuchkarov, 2011).

So, we hypothesize:

H1h: Higher usage of IT leads to higher innovativeness of SMEs

\subsection{Training for managers}

Thinking straightforwardly, one can assume that training has positive bearing on increasing human knowledge and awareness of different changes happening around. Since knowledge is a base for new knowledge generation that is an essential step in innovation, many researchers investigated training effect on innovative performance of firms. Most of the empirical researches yield results pointing to positive relationship between training and innovation (Rogers, 2004; Santamaria, 2009). (Gabsi, 2008) points to the problem of training and upgrading of senior managers as an explanation for very weak relationship of worker skills factor with innovation performance in Tunisian firms. Analysis from (Rogers, 2004) indicates that both in manufacturing and non-manufacturing firms, both product and process innovations are higher in those with higher management training. (Santamaria, 2009) sees training activities to be a key factor for the achievement of innovations in low and medium technology firms. Lack of training is showed to be one of the constraints to innovativeness in UK SME case (Laforet, 2006). Additionally, significance of learning orientation in organizations in enhancing innovativeness has also been extensively researched and has been agreed by many that learning orientation has great effect on firm innovativeness (Jaehoo, 2010; Roger J, 2002). Organizations prioritizing learning is said to enhance its innovation capability in three ways: because of their higher commitment to innovation, their fastness in catching market opportunities owing to their knowledge and ability to understand the market and their greater innovation capabilities compared to their competitors due to their inherent characteristics of monitoring them (Roger J, 2002). Learning by doing, learning by training and learning by interacting has been defined to have the highest impact on novelty of innovation in SMEs (Amara, 2008). (Freel, 2005) investigating the bearing of training on innovation in Northern England SMEs finds innovations to be highly linked to firm-level training intensity. His research confirms that the most innovative firms train more staff. Growth-oriented SMEs provide more formal training and experiential learning activities which is accounted to be important to the development of a firm's absorptive capacity (Colin, 2006). Investment in knowledge, measured through training expenditures is positively and significantly linked to innovativeness (Tessa, 2004). Therefore, improvement and training programs are advised for executive and employees.

So, we hypothesize:

H1i: Trainings for managers leads to higher innovativeness of SMEs

\subsection{External factors bearing to firm innovativeness}

External factors refer to opportunities that SME can seize from its environment which are believed to have some impact on its innovativeness (Keizer, 2002). 


\subsection{Networking}

Innovation process is not purely an internal process. Firms, especially small and medium ones (Hoffman, 1998) usually seek to cooperate with external linkages such as universities, research institutes etc., in their attempt to generate innovations. Empirical tests found networking to be one of the main predictors of firm innovativeness (Rogers, 2004; Radas, 2009). (Rogers, 2004) finds this variable to be highly linked with product and process innovations both in manufacturing and non-manufacturing Australian firms and states that particularly SMEs may rely more heavily on external knowledge networks as an input to innovation. Further, more specific results on Croatian SMEs from (Radas, 2009) enlightens the fact that collaboration with other firms or organizations puts more impact on process and incremental product innovation, whereas, links with academic and research institutions bear more on radical product innovation. (Santamaria, 2009) emphasizes the use of consultants, the hiring of personnel and external R\&D collaborations to be particularly significant external sources of innovation (particularly in process innovations) in low and medium technology industries. Larger networks and bottom up formed networks has been proven to achieve greater innovative performance (Sara, 2009). Significant positive relationship between inter-firm cooperation, cooperation with intermediary institutions, cooperation with research organizations and innovation performance of SMEs has been empirically established by a study from Zeng (2010). The concept of open innovation system which implies active interaction of government, universities and non-profit research and business development centers with SME has been proposed as a tool to increase the sustainability of Indonesian SMEs (Jahja, 2012). Empirically substantiating a strong positive relationship between the strength of cooperative ties and SME innovative capability, (Philip, 2013) also states the importance of policy towards nurturing and sustaining SME innovation networks.

So, we hypothesize:

H1j: SME's networking efforts are positively associated with its innovativeness

\subsection{Market dynamism (Market competition)}

Being innovative is seen as a counter-attack strategy to harsh competition. Mostly it is about the competition; firms are naturally compelled to think about doing something in order to survive and keep growth. The concentration level of competitors in the market determines the need to undertake innovations (Schumpeter, 1942; Ahn, 2002) There is a collection of several theoretical cases which explain conduciveness of competition to innovation: based on Darwinian effect, intensified product market competition is said to become a main force to make managers adopt new technologies; in neck-and-neck competition effect, competition between firms with "neck-and-neck" technologies is stated to affect to firm's incentive to increase its technological lead over its competitors. Survival on competitive markets requires innovations happen (Radas, 2009). Competitive pressures positively affect firms' inclination to undertake R\&D (Kumar, 1996) which is the main innovation activity. (Gabsi, 2008), in the case of Tunisian firms, finds that the increase in concentration of the market implies an increase in the probability of innovation in examined companies. It is because competitive firms can make a comparison between them and their competitors and easily identify a better strategy and therefore they may be more likely to try low cost innovations than a monopoly may (Sunku, 2010). So, limited number of clients and suppliers are found to limit a firm's outlook and has a negative effect on innovation outputs (Santamaria, 2009). Thin markets tend to stifle innovation whereas in-action marketplace with multiple buyers and sellers conditions private innovations thrive (PwC, 2010). The Industrial Cluster approach stresses the competitive pressure of the environment on the firm essential to the process of innovation (Silva, 2008).

So, we hypothesize:

H1k: SMEs operating in more competitive environments show higher innovativeness

\subsection{Public incentives}

Generally, government innovation policy embraces both financial and non-financial measures (Sunil, 2002). Government incentives refer to financial measures including government subsidies, tax incentives, custom 
duty releases, funding (PwC, 2010) and etc. Public incentive measures which are widely used in promoting innovations in Europe are financing for innovation projects, support to networking, awareness raising and technology transfer (PRO INNO, 2009). Hence, there is a question that asks if government incentives have some bearing on innovation performance of the receiver. Successful countries in fostering innovation is said to build a tax platform which encourage innovations through a tax holiday, an overall low tax rate, or industry-specific low tax rates, an R\&D tax regime; an intellectual property tax regime and also focus on the investor side of taxes by removing double taxation (PwC, 2010). (Keizer, 2002) found innovative efforts of the firm to be positively linked with governmental innovation subsidy, which is one type of government incentives. Findings of (Liqin, 2010) confirm government innovation policy to have positive influence on the Chinese companies' innovation performance. By counting different disadvantageous features of small business like limitedness in resources and appropriately in their capabilities for in-house R\&D, weak external contacts, underdeveloped education and training and their over-involvement in operational level decisions, Silvia (2008) advocates crucial role of public intervention by national governments. Research (Antonia, 2009) on defining innovation barriers among Spanish SMEs recommends that public policy which encourages innovation can enable firms to remain competitive and survive.

So, we hypothesize:

H1l: SMEs using public incentives show higher innovativeness

\subsection{Dominant market (Export characteristics)}

Export-orientation and innovation performance have also been found positively interconnected (Chiara, 2010; Rogers, 2004; Pla-Barber, 2007; Radas, 2009). Local and even national customer networks appear to be less well performing in relation to innovative behavior of the firm compared to leading international markets links (Romijn, 2002). Rising exporting is associated with more probability and intensity of investment in R\&D (Kumar, 1996). Higher innovativeness of exporting companies is explained as firm's attempt of survival on more competitive markets (Radas, 2009) and higher incentives owing to its access to improved knowledge flows (Rogers, 2004). (Rogers, 2004) empirically confirms that exporting manufacturing firms are more innovative in terms of their product and process innovations. (Chiara, 2010) states that globally engaged firms tend to have more product and process innovations comparing to their purely domestic counterparts and it is because the knowledge of how to innovate is effectively transmitted to exporting firms from markets abroad, intra-firm worldwide pool of information (in the example of multi-nationals), their supplier and customers. In the example of Northern England SMEs, (Freel, 2003) notes that novel innovators are those who are marked by greater geographical extent of their innovation links (from local to regional further national and overseas) while incremental product innovators are more locally embedded. (Guido, 2001) compares exporter and non-exporter small Italian manufacturing firms in terms of some specific features they may distinguish and find those which have succeeded in entering foreign markets to have an ability to innovate in products. Case study research on three auto component SMEs of Bangalore draws to conclusions that a natural development of the process of innovation is the entry of these SMEs into international markets and further facilitation of their learning process (Krishnaswamy, 2014).

So, we hypothesize:

H1m: Export oriented SMEs are more innovative than locally oriented ones

\section{Methodology}

This research targeted small and medium enterprises (SMEs) of Uzbekistan and China and intended to find SME innovativeness characteristics using survey questionnaires for data collection. We have successfully collected 402 completed questionnaires with a return rate of $80.4 \%$ in Uzbekistan and 563 completed questionnaires with a return rate of $59.2 \%$ in China cases. Out of 402 and 563 completed questionnaires, 362 and 412 pieces were usable which response rates of $72.4 \%$ and $43.3 \%$ accordingly. 
We chose Logistic Regression Model for our research analysis, with the premise of applying this model enables us to explain behavior of innovative SMEs. The use of Logit model aids to make inference on impact of all independent variables onto the dependent variables. In order to check significance of relationship separately we considered the affecting factors and dependent variables, and applied the Bivariate Relationship Statistics. Chi-square and McFadden's R2 were also applied to check significance in Logistic Model.

To measure innovativeness of SMEs as our dependent variable we defined value $=1$ if new or incremental product or process innovations occurred in the firm within last three year, value $=0$ otherwise.

We defined our independent variables in following way;

1. Firm size: "1" if the SME size is bigger than median value of the set; "0" otherwise;

2. Firm age: "1" if the SME age is bigger than median value of the set then; "0" otherwise;

3. Proportion of qualified personnel: we defined proportion of qualified personnel by calculating percentage for the number of employees with university degree in the total number of employees working in SMEs. We assigned " 1 " if that proportion is bigger than median value of the set; "0" otherwise;

4. Education of the SME CEO:

a) Degree: " 1 " if it is a university degree, " 0 " if it is college degree or less;

b) Place of the education: " 1 " if it is from abroad; "0" if it is from college/university at home;

5. CEO perception of innovation: "1" if he/she agrees that he/she has been always thinking about implementing innovation-goal-orientation in the company strategy; "0" otherwise;

6. Employee engagement in innovation process: "1" if respondent agrees that they welcome new ideas from all the employees and support; " 0 " otherwise;

7. Training for managers: " 1 " if SME holds trainings for managers; " 0 " otherwise;

8. IT capabilities: Likert scale evaluation of IT usage in SME to contact with suppliers, customers and to collect useful information and to the betterment of the work processes from 1 (bad) to 5 (excellent);

9. Networking: "1" if SME states relations with one or more number of knowledge/technology centers; "0" otherwise;

10. Market dynamism (market competition): "1" if respondent states high competition in his/her sector market from national and international competitors; " 0 " if competitors are very limited in number;

11. Public incentives: " 1 " if respondent states usage of any recent public incentives offered from the government implying better engagement of SMEs into innovation; "0" otherwise;

12. Export characteristics: "1" if respondent states fifty or more percent of the total production to be sold in international market; "0" otherwise;

\section{Findings and discussions}

Our findings reveal some similarities and differences between Uzbekistan and China SME innovativeness affecting factors possibly due to economic, management and social differences between these two developing countries. Our results indicate that although the model doesn't fit in a perfect way in each country, it is a useful framework for investigating important factors of SME innovativeness in developing countries. In relation to those variables which got only one sided support, there is a lesson for the other country to learn from its counterpart. 
Ahunjonov Umidjon, Hu Shuhua, Bandula Jayathilake, Mu Renyan

Characteristics of Small and Medium Enterprise Innovativeness: Cases of Uzbekistan and China

\begin{tabular}{|c|c|c|c|c|}
\hline № & Hypotheses & $\begin{array}{l}\text { Uzbekistan } \\
\text { SMEs }\end{array}$ & China SMEs & Overall \\
\hline \multicolumn{5}{|c|}{ Affecting Factors } \\
\hline \multicolumn{5}{|c|}{ Internal factors } \\
\hline 1. & Firm size $\rightarrow$ mnovativeness ( $\mathrm{H} 2 \mathrm{a}$ ) & $\begin{array}{l}\text { Not } \\
\text { Supported }\end{array}$ & $\begin{array}{c}\text { Not } \\
\text { Supported }\end{array}$ & Not supported \\
\hline 2. & Firm age $\rightarrow$ innovativeness ( $\mathrm{H} 2 \mathrm{~b}$ ) & $\begin{array}{c}\text { Not } \\
\text { Supported }\end{array}$ & $\begin{array}{l}\text { Supported } \\
\text { (neg.) }\end{array}$ & Inconclusive \\
\hline 3. & $\begin{array}{l}\text { Proportion of qualified personnel } \rightarrow \\
\text { Innovativeness }(\mathrm{H} 2 \mathrm{c})\end{array}$ & $\begin{array}{c}\text { Not } \\
\text { Supported }\end{array}$ & $\begin{array}{c}\text { Not } \\
\text { Supported }\end{array}$ & Not supported \\
\hline 4. & CEO Degree $\rightarrow$ Innovativeness $(\mathrm{H} 2 \mathrm{~d})$ & Supported & Supported & Supported \\
\hline 5. & $\begin{array}{l}\text { Place of CEO Education } \rightarrow \\
\text { Innovativeness }(\mathrm{H} 2 \mathrm{e})\end{array}$ & $\begin{array}{c}\text { Not } \\
\text { Supported }\end{array}$ & $\begin{array}{c}\text { Not } \\
\text { Supported }\end{array}$ & Not supported \\
\hline 6. & $\begin{array}{l}\text { Innovation goal orientation of CEO } \rightarrow \\
\text { Innovativeness }(\mathrm{H} 2 \mathrm{f})\end{array}$ & Supported & Supported & Supported \\
\hline 7. & $\begin{array}{l}\text { Employee engagement in innovation } \\
\text { process } \rightarrow \text { Innovativeness }(\mathrm{H} 2 \mathrm{~g})\end{array}$ & $\begin{array}{l}\text { Supported } \\
\text { (neg.) }\end{array}$ & $\begin{array}{c}\text { Not } \\
\text { Supported }\end{array}$ & Inconclusive \\
\hline 8. & IT capabilities $\rightarrow$ Innovativeness ( $\mathrm{H} 2 \mathrm{~h}$ ) & Not supported & $\begin{array}{l}\text { Supported } \\
\text { (neg.) }\end{array}$ & Inconclusive \\
\hline 9. & $\begin{array}{l}\text { Training for managers } \\
\text { Innovativeness (H2i) }\end{array}$ & $\begin{array}{l}\text { Not } \\
\text { Supported }\end{array}$ & $\begin{array}{c}\text { Not } \\
\text { Supported }\end{array}$ & Not supported \\
\hline \multicolumn{5}{|c|}{ External factors } \\
\hline 10. & Networking $\longrightarrow$ novativeness $(\mathrm{H} 2 \mathrm{j})$ & Supported & $\begin{array}{l}\text { Not } \\
\text { Supported }\end{array}$ & Inconclusive \\
\hline 11. & $\begin{array}{l}\text { Market competition } \rightarrow \text { Innovativeness } \\
(\mathrm{H} 2 \mathrm{k})\end{array}$ & Supported & Supported & Supported \\
\hline 12. & $\begin{array}{l}\text { Public incentives for innovations } \\
\text { Innovativeness }(\mathrm{H} 2 \mathrm{l})\end{array}$ & Supported & Supported & Supported \\
\hline 13. & $\begin{array}{l}\text { Export characteristics } \rightarrow \\
\text { Innovativeness }(\mathrm{H} 2 \mathrm{~m})\end{array}$ & Supported & Supported & Supported \\
\hline
\end{tabular}

Table 4-1: Hypothesis testing results

Firm size wasn't found to be a significant antecedent of SME innovation behavior in both of our samples. This means that size of the company is not a determinant of its innovativeness. Regardless of the size, any company is able to innovate if it is willing to do so. Finding no relationship between innovations and firm size, (Pla-Barber, 2007) suggests the industrial setting to be taken into account. He states that in science based industries (e.g. biotechnology) size doesn't bear any impact on innovations since most of the innovations are the work of single scientist in the firm. Even though, this interpretation doesn't fit the characteristics of our sample, we can say that innovations are not only limited to breakthroughs, rather, it is more likely to happen in incremental way in developing countries. Thus, small firms of any size are able to introduce at least incremental innovations if they have a culture for fostering innovations.

Relationship regarding firm age and innovativeness was shown to be significant only in China SME case. The model shows younger SMEs to be more innovative. Even though the relationship is inconclusive due to support by only one case, direction of the relationships supports findings from (Hansen, 1992) and (Huergo, 2004). The reason why only Chinese SME case presents significance implying younger SMEs to be more innovative compared to older aged ones is maybe also due to broader opportunities and favorable conditions Chinese Government created for start-ups to grow and better niche-market orientation characteristics of 
Chinese SMEs; in GII-2013 report China occupies 118th place while Uzbekistan takes 54th for ease of starting a business index.

Proportion of highly educated workers didn't show any significant relationship to propensity of SMEs to innovate. Seems higher education of workers itself doesn't lead to innovations unless there is a culture or established system which manages human capital to the sake of making innovations happen. Not finding any positive effect of employee skills (quantified by the type of diploma) on the decision of firms to innovate in the sample of Tunisian firm level data (Gabsi, 2008) also states use of skilled labor not to be enough to innovate.

Significantly positive links between CEO university education (opposed to CEO college education or less) and innovation output in both cases signals important effect of CEO higher education in SME innovativeness. This finding is in harmony with findings of other literature (Hoffman, 1998; Lin, 2011). It holds truth that higher education is important in a sense that it opens the eyes of a person to wider horizons and it gives the person different perspective and view. As it is stated in Mohamed (2005), highly educated owners will show a positive outlook towards creativity and innovativeness, which in the end leads to realization of innovations. Higher R\&D spending inclination by higher degree CEOs (Datta, 1994; Yan Yong-hai, 2010; Barker, 2002) also consequently leads to more innovation output from R\&D activities.

SMEs with CEOs who always think about implementing innovation-goal-oriented strategy shows higher propensity to innovate meaning that innovation-conscious CEOs are the ones who are driving innovations in their organizations. CEOs who can envision further survival and prosperity of their firm within harshly competitive markets (Colin, 2006) seek for some ways (innovation efforts) to keep innovative. This finding also comes in line with thoughts of (Schumpeter, 1934) who calls entrepreneurs as "innovators - catalysts of change who continuously do things that have not been done before". Entrepreneur CEOs' is a prime factor who is responsible for the emergence and implementation of innovations (Krishnaswamy, 2014). In the end, this all comes with strategic plan for innovations by the owner/CEO of the company and his/her persistence pursuing the plan.

According to the result of our inference model, no significant relationship was defined between "Place of CEO education" variable and SME innovativeness. Seems it is not about having education abroad, but mostly it is about being able to understand the urge to be innovative and leading innovativeness appropriately. As we can see, other CEO related variables showed strong relationship to the propensity of innovation happen in the firm, meaning that it is mostly CEO intention to realize innovations and his higher education degree in general which makes the SME innovate, not the place of CEO education per se.

We have observed negative effect of information technologies and employee engagement in innovation process on SMEs innovativeness in the case of single China and Uzbekistan respectively. Most probably, this shortfall of the use of IT and employee for innovations is mainly due to mismanagement or deficiencies in planning and organization. As it was stated in (Lubica, 2014), employees' interest to develop innovation activities requires a certain level of pro-innovative culture in the company. Supporting organization structure and management team is counted responsible in the end to put ideas from employees into forth (McAdam, 2004). In similar way, usage of IT has to be directed in a way that it helps innovations prosper by being a tool to acquire, synthesize and exchange necessary information for innovations. Seems, as stated in (Oslo Manual, 2005) incorporation of ICTs are still being limited to only sophisticated "front-office" applications. Still, overall finding based on two country example is denoting the results to be inconclusive. Future research work is needed to determine this.

Trainings provided for managers variable wasn't shown to be a significant distinguishing factor between more and less innovative SMEs in developing countries. This finding is contrary to previous literature which state positive relationship between training and firm innovativeness. Seems, training programs being planned are 
not yet in a direction or in a quality to equip managers with necessary knowledge on critical importance of innovations and on how to have them happen in developing countries. Results show that training itself doesn't translate into innovations.

Competitive markets were found to be a powerful positive antecedent of SME innovativeness and its positive relationship with SME innovativeness was proved with both of our samples at the same time. SMEs in competitive markets are more inclined to innovate. Seems, SMEs in competitive markets are innovating not because of only pressures from competitors (Gabsi, 2008), but also (Wai-sum, 2006; Sunku, 2010) through knowledge obtained by seeing innovative products from competitors surrounding them.

Relation with knowledge centers is found to be positively and significantly supportive to SME innovativeness only in the case of Uzbek SMEs. In China case though, relationship is positive but insignificant. The reason why link between innovation outputs and knowledge centers variables is not significant in China case may have some backgrounds from previous literature (Fuxin, 2006; Yueping, 2002; Wang Lei, 2008) which states the lack of sound cooperation among Chinese enterprises with others institutions. Seems SME cooperation with knowledge centers in China is always not yielding intended results. Another point to note here is that there are sectoral and geographical differences stated in the impact of this factor on innovativeness by (Hoffman, 1998) and (Birchall et al., 1996).

Export oriented SMEs; those which sell more than fifty percent of their production to foreign markets are shown by our data analysis to be more innovative than their locally oriented peers both in China and Uzbekistan sample. Our finding which states export orientation and its strongly positive effect on firm innovativeness is in compliance with findings of many previous studies (Chiara, 2010; Rogers, 2004; PlaBarber, 2007; Radas, 2009). Export oriented companies seem to pay more attention to innovations through investing more on R\&D activities or engaging in other non-R\&D activities in their attempt to survive in a more demanding markets with higher standards. Because wider markets offer more opportunities and quality networks, seems, exporting SMEs naturally taking advantage of this knowledge pool to better innovate.

With regard to public incentives and their impact on SME innovativeness, a strong positive relationship has been revealed in both cases concurrently. Our finding is in step with findings of several other studies which empirically found a positive link between public support and firm innovativeness (Keizer, 2002, Liqin, 2010). Well-understanding their own disadvantageous features like their weakness in terms of financing, R\&D, training and external contacts (Silvia, 2008) seems, innovative SMEs seek for any possible public support which comes in favorable terms and conditions to realize their innovations. The innovative strategy of SMEs has to be linked to that of local government agencies to provide targeted funding for innovation-based improvements (McRodney, 2004). This finding increases importance of availability of public supports.

\section{Conclusion}

The main objective of our research was to increase our knowledge about main predictors of innovation behavior of SMEs based on our sample SMEs from two developing countries. We tried to explain "how's" and "why's" of SME innovation behavior.

CEOs with higher education, their innovation goal-oriented determination, and competition pressure from home market and abroad due to high export orientation of the SME and government incentives for innovations are being main forces making SMEs realize innovations. Internally, innovative SMEs are being led by CEOs with higher education degree and who well fits the great importance of innovations in their company strategy. Innovative companies have also reported that their home market is competitive enough and they sell more than fifty percent of their production abroad which means that they play in the market feeling harsh competition inside and outside. And, to our opinion, especially those companies are 
advantageously and skillfully using some types of available public incentives to financially support their innovations.

Learnt lessons from the findings of this study bring us to following conclusions.

- As it was proven in our results, innovativeness is a deliberately chosen and pursued policy which is mostly pushed by Government-built market infrastructure (public innovation oriented policy, pure competitive business environment, export support and availability of knowledge providing actors) and by highly educated CEO efforts. Since the State plays an important role as regulator and intermediary between different actors of innovation system as well as a regulator of financing structures to innovations, its intervention to enhance innovativeness of country's national companies, particularly SMEs, is highly important.

- Environments conducive to SME innovativeness are significantly different even within the context of different developing countries which results in the different extents of innovation outputs and in-process innovation activities. This necessitates a need for benchmarking.

- Most of the determinants which were found to have some impact on firm innovativeness in different contexts are equally important for developing country SMEs;

- Innovativeness can at least partially be controlled by management, policy-directed action;

- Market environment (domestic market competition, availability of public support, environment that supports exports) and firms' strategic attitude (CEO innovation orientation) in general are main driving forces for innovations as it is stated in several other studies;

Given the key role of innovations in economic growth, wealth creation and prosperity of the nations, the results of our empirical study serve to be important lessons for other developing countries of the world.

\section{References}

- Ahn, S. (2002). Competition, innovation and productivity growth. OECD.

- Alberto Marcati, Guido, G., \& Peluso, A. M. (2008). The role of SME entrepreneurs' innovativeness and personality in the adoption of innovations. Research Policy,37(9), 1579-1590.

- Amara, N., Landry, R., Becheikh, N., \& Ouimet, M. (2008). Learning and novelty of innovation in established manufacturing SMEs. Technovation, 28(7), 450-463.

- Andre Spithoven, Clarysse, B., \& Knockaert, M. (2011). Building absorptive capacity to organise inbound open innovation in traditional industries.Technovation, 31(1), 10-21.

- AnnaLee Saxenian (2005). From brain drain to brain circulation: Transnational communities and regional upgrading in India and China. Studies in Comparative International Development, 40(2), 3561.

- Antonia Madrid-Guijarro, Garcia, D., \& Van Auken, H. (2009). Barriers to innovation among Spanish manufacturing SMEs. Journal of Small Business Management, 47(4), 465-488. 
- Banker, R. D., Bardhan, I., \& Asdemir, O. (2006). Understanding the impact of collaboration software on product design and development. Information Systems Research, 17(4), 352-373.

- Barker III, V. L., \& Mueller, G. C. (2002). CEO characteristics and firm R\&D spending. Management Science, 48(6), 782-801.

- Bertschek, I., \& Entorf, H. (1996). On nonparametric estimation of the Schumpeterian link between innovation and firm size: evidence from Belgium, France, and Germany. Empirical Economics, 21(3), 401-426.

- Birchall, D., Chanaron, J. and Soderquist, K. (1996), "Managing innovation in SMEs: a comparison of companies in the UK, France and Portugal", International Journal of Technology Management, Vol. 12 No. 3, pp. 291-305.

- Carbonara, N. (2005). Information and communication technology and geographical clusters: opportunities and spread. Technovation, 25(3), 213-222.

- Cheng Jen Huang, and Chun Ju Liu. "Exploration for the relationship between innovation, IT and performance." Journal of Intellectual Capital 6.2 (2005): 237-252.

- Chiara Criscuolo, Haskel, J. E., \& Slaughter, M. J. (2010). Global engagement and the innovation activities of firms. International Journal of Industrial Organization, 28(2), 191-202.

- Colin G. (2006). Absorptive capacity, knowledge management and innovation in entrepreneurial small firms. International Journal of Entrepreneurial Behaviour \& Research, 12(6), 345-360..

- Datta, D. K., \& Guthrie, J. P. (1994). Executive succession: Organizational antecedents of CEO characteristics. Strategic Management Journal, 15(7), 569-577.

- Desouza, K. C., Awazu, Y., Jha, S., Dombrowski, C., Papagari, S., Baloh, P., \& Kim, J. Y. (2008). Customer-driven innovation. Research-Technology Management, 51(3), 35-44.

- Eric Von Hippel. Democratizing Innovation. The MIT Press, 2005.

- Frederic Bougrain, \& Haudeville, B. (2002). Innovation, collaboration and SMEs internal research capacities. Research Policy, 31(5), 735-747.

- Freel, M. S. (2003). Sectoral patterns of small firm innovation, networking and proximity. Research policy, 32(5), 751-770.

- Freel, M. S. (2005). Patterns of innovation and skills in small firms. Technovation, 25(2), 123-134.

- Freel, M.S. (2005), "The characteristics of innovation-intensive small firms: evidence from Northern Britain", International Journal of Innovation Management, Vol. 9 No. 4, pp. 401-29.

- Fuxin Jiang, Zhou Chunping (2006). China's small enterprises in economic transition: successes and problems. Indian Journal of Economics and Business, Special issue China \& India (1).

- Gabsi, F., Mhenni, H., \& Koouba, K. (2008). Innovation determinants in emerging countries: an empirical Study at the Tunisian firm level.

- Guido Nassimbeni (2001). Technology, innovation capacity, and the export attitude of small manufacturing firms: a logit/tobit model. Research Policy, 30(2), 245-262.

- Hansen, J. A. (1992). Innovation, firm size, and firm age. Small Business Economics, 4(1), 37-44.

- Hoffman, K., Parejo, M., Bessant, J., \& Perren, L. (1998). Small firms, R\&D, technology and innovation in the UK: a literature review. Technovation, 18(1), 39-55.

- Huergo, E., \& Jaumandreu, J. (2004). How does probability of innovation change with firm age?. Small Business Economics, 22(3-4), 193-207.

- Ignas Sidik (2012). Conceptual framework of factors affecting SME development: Mediating factors on the relationship of entrepreneur traits and SME performance. Procedia Economics and Finance, 4, 373-383.

- Jaehoo, .R, Park, T., \& Lee, D. H. (2010). Drivers of innovativeness and performance for innovative SMEs in South Korea: Mediation of learning orientation. Technovation, 30(1), 65-75.

- Jahja Hamdani, \& Wirawan, C. (2012). Open Innovation Implementation to Sustain Indonesian SMEs. Procedia Economics and Finance, 4, 223-233.

- Jeff Dyer, Hal Gregersen, and Clayton M. Christensen. The innovator's DNA: Mastering the five skills of disruptive innovators. Harvard Business Press, 2011. 
- Joan Johnson, (2002). Reverse Brain Drain and the Global Diffusion of Knowledge, The. Geo. J. Int'I Aff., 3, 125.

- Jon Sundbo. (1996). The balancing of empowerment. A strategic resource based model of organizing innovation activities in service and low-tech firms.Technovation, 16(8), 397-446.

- Keizer, J. A., Dijkstra, L., \& Halman, J. I. (2002). Explaining innovative efforts of SMEs.: An exploratory survey among SMEs in the mechanical and electrical engineering sector in The Netherlands. Technovation, 22(1), 1-13.

- Koberg, C. S., Detienne, D. R., \& Heppard, K. A. (2003). An empirical test of environmental, organizational, and process factors affecting incremental and radical innovation. The Journal of High Technology Management Research,14(1), 21-45.

- Krishnaswamy, K. N., Mathirajan, M., \& Bala Subrahmanya, M. H. (2014). Technological innovations and its influence on the growth of auto component SMEs of Bangalore: A case study approach. Technology in Society, 38, 18-31.

- Kuchkarov A. National Innovation System in Uzbekistan: Capacity and Performance Assesment, Published in Uzbekistan , 2011, www.undp.uz

- Kumar, N., \& Saqib, M. (1996). Firm size, opportunities for adaptation and in-house R\&D activity in developing countries: the case of Indian manufacturing.Research Policy, 25(5), 713-722.

- Laforet, S., \& Tann, J. (2006). Innovative characteristics of small manufacturing firms. Journal of Small Business and Enterprise Development, 13(3), 363-380.

- Lehrer, M., \& Asakawa, K. (2004). Pushing scientists into the marketplace: Promoting science entrepreneurship. California Management Review, 46(3), 55-76.

- Lin, C., Lin, P., Song, F. M., \& Li, C. (2011). Managerial incentives, CEO characteristics and corporate innovation in China's private sector. Journal of Comparative Economics, 39(2), 176-190.

- Liqin R., Zeng, D., \& Krabbendam, K. (2010). Technological innovation progress in

- Central China: a survey to 42 firms. Journal of Knowledge-based Innovation in China, 2(2), 152-170.

- Lubica Lesáková (2014). Evaluating Innovations in Small and Medium Enterprises in Slovakia. Procedia-Social and Behavioral Sciences, 110, 74-81.

- Making public support for innovation in the EU more effective, (PRO INNO) Europe ${ }^{\circledR}$ Paper N13 Commission Staff Working Document SEC (2009)1197, 2009.

- Manjit Yadav, S., Prabhu, J. C., \& Chandy, R. K. (2007). Managing the future: CEO attention and innovation outcomes. Journal of Marketing, 71(4), 84-101.

- Marco lansiti. (1995). Technology integration: managing technological evolution in a complex environment. Research policy, 24(4), 521-542.

- Marianna Makri \& Scandura, T. A. (2010). Exploring the effects of creative CEO leadership on innovation in high-technology firms. The Leadership Quarterly,21(1), 75-88.

- McAdam, R., McConvery, T. and Amstrong, G. (2004), "Barriers to innovation within small firms in a peripheral location", International Journal of Entrepreneurial Behaviour \& Research, Vol. 10 No. 3, pp. 206-21.

- Minna Saunila \& Ukko, J. (2014). Intangible aspects of innovation capability in SMEs: Impacts of size and industry. Journal of Engineering and Technology Management, 33, 32-46.

- Mohamed Mostafa. (2005). Factors affecting organisational creativity and innovativeness in Egyptian business organisations: an empirical investigation.Journal of Management Development, 24(1), 7-33.

- Oslo Manual, Guidelines for collecting and interpreting innovation data, OECD, 2005

- Philip Tomlinson \& Fai, F. M. (2013). The nature of SME co-operation and innovation: A multi-scalar and multi-dimensional analysis. International Journal of Production Economics, 141(1), 316-326.

- Pla-Barber, J., \& Alegre, J. (2007). Analysing the link between export intensity, innovation and firm size in a science-based industry. International Business Review, 16(3), 275-293.

- Povl. H, \& Serin, G. (1997). Will low technology products disappear?: The hidden innovation processes in low technology industries. Technological Forecasting and Social Change, 55(2), 179-191. 
- PwC (Price water house Coopers), Innovation: Government's Many Roles in Fostering Innovation, 2010.

- Radas, S., \& Božić, L. (2009). The antecedents of SME innovativeness in an emerging transition economy. Technovation, 29(6), 438-450.

- Roger, C J., Cavusgil, S. T., \& Zhao, Y. (2002). Learning orientation, firm innovation capability, and firm performance. Industrial marketing management,31(6), 515-524.

- Rogers, M. (2004). Networks, firm size and innovation. Small Business Economics, 22(2), 141-153.

- Roman Kmieciak, Michna, A., \& Meczynska, A. (2012). Innovativeness, empowerment and IT capability: evidence from SMEs. Industrial Management \& Data Systems, 112(5), 707-728.

- Romijn, H., \& Albaladejo, M. (2002). Determinants of innovation capability in small electronics and software firms in southeast England. Research policy,31(7), 1053-1067.

- Santamaria, L., Nieto, M. J., \& Barge-Gil, A. (2009). Beyond formal R\&D: Taking advantage of other sources of innovation in low-and medium-technology industries. Research Policy, 38(3), 507-517.

- Santarelli, E., \& Sterlacchini, A. (1990). Innovation, formal vs. informal R\&D, and firm size: some evidence from Italian manufacturing firms. Small Business Economics, 2(3), 223-228.

- Sara Thorgren, Wincent, J., \& Örtqvist, D. (2009). Designing interorganizational networks for innovation: An empirical examination of network configuration, formation and governance. Journal of Engineering and Technology Management,26(3), 148-166.

- Schumpeter J. (1942) "Capitalism, Socialism \& Democracy".

- Schumpeter J.A. (1934) The Theory of Economic Development: An Inquiry into Profits, Capital, Credit, Interest, and Business Cycle. Massachusetts. Harvard University Press,

- Shefer, D., \& Frenkel, A. (2005). R\&D, firm size and innovation: an empirical analysis. Technovation, 25(1), 25-32.

- Silvia Massa \& Testa, S. (2008). Innovation and SMEs: Misaligned perspectives and goals among entrepreneurs, academics, and policy makers. Technovation,28(7), 393-407.

- Stock, G. N., Greis, N. P., \& Fischer, W. A. (2002). Firm size and dynamic technological innovation. Technovation, 22(9), 537-549.

- Sunil Mani, Government, Innovation and Technology Policy, The United Nations University, Tokyo, 2002

- Sunku Hahn. (2010). Competition, comparison, and innovation. Economics Letters,106(2), 122-124.

- Tessa A., Viaene, J., Morgan, E. J., Pitts, E., Crawford, N., \& Mahon, D. (2004). Determinants of product and process innovation in small food manufacturing firms. Trends in Food Science \& Technology, 15(10), 474-483.

- Wai-sum Siu, Lin, T., Fang, W., \& Liu, Z. C. (2006). An institutional analysis of the new product development process of small and medium enterprises (SMEs) in China, Hong Kong and Taiwan. Industrial Marketing Management, 35(3), 323-335.

- Wang Lei. SME Development Policies in China, A Country Paper for the Workshop on SME Development and Regional Economic Integration, September 22-26, 2008, Tokyo

- Xiaohui Liu, Lu, J., Filatotchev, I., Buck, T., \& Wright, M. (2010). Returnee entrepreneurs, knowledge spillovers and innovation in high-tech firms in emerging economies. Journal of International Business Studies, 41(7), 1183-1197.

- Xiaolan Fu, Pietrobelli, C., \& Soete, L. (2011). The role of foreign technology and indigenous innovation in the emerging economies: Technological change and catching-up. World development, 39(7), 1204-1212.

- Yan Yong-hai, Impact of CEO Characteristics on Enterprise R\&D Expenditure, 3rd International Conference on Information Management, Innovation Management and Industrial Engineering, (C) 2010 IEEE

- Yueping Wang., \& Yao, Y. (2002). Market reforms, technological capabilities and the performance of small enterprises in China. Small Business Economics, 18(1-3), 195-209. 
- Zeng, S. X., Xie, X. M., \& Tam, C. M. (2010). Relationship between cooperation networks and innovation performance of SMEs. Technovation, 30(3), 181-194.

- Zhang Man, Sarker, S., \& Sarker, S. (2008). Unpacking the effect of IT capability on the performance of export-focused SMEs: a report from China. Information Systems Journal, 18(4), 357-380.

- Silva, M. J., Leitao, J., \& Raposo, M. (2008). Barriers to innovation faced by manufacturing firms in Portugal: how to overcome it for fostering business excellence?. International Journal of Business Excellence, 1(1), 92-105. 